American Journal of Animal and Veterinary Sciences 5 (2): 159-162, 2010

ISSN 1557-4555

(C) 2010 Science Publications

\title{
Histological Study of Cervix Uteri in Caspian Miniature Horse
}

\author{
M. Rezaian and S. Hamedi \\ Division of Histology, Department of Basic Sciences, \\ Faculty of Veterinary Medicine, University of Tehran, \\ P.O. Box 14155-6453, Tehran, Iran
}

\begin{abstract}
Problem statement: Uterine cervix which separates the uterus from the vagina, shows remarkable anatomical and histological differences among mammalian species. Since no cleared observations have been found in regards with the Caspian miniature horses' cervix, the aim of the present study was to supplement this missing information which could be helpful for providing a stricter basis in detecting reproductive diseases and abnormalities in this valuable species. Approach: Cervices from 4 female adult healthy Caspian miniature horses dissected immediately after death and samples of $1 \mathrm{~cm}$ thickness from 3 regions of cervix (endocervix, midcervix and exocervix) fixed with $10 \%$ buffered formalin. Routine histological laboratory methods were used and $6 \mu \mathrm{m}$ paraffin slides stained with hematoxylin-eosin, Periodic acid-Schiff, Masson's trichrome and verhoeff methods and studied under light microscope. Heights of primary, secondary and tertiary folds and mucosal glands measured with computer software. Results: The cervix comprised of primary, secondary and tertiary fold with Simple columnar epithelium in endocervix and midcervix and most cranial part of the exocervices and changes into the non keratinized stratified squamous and a transitional form with stratified squamous with columnar cells, near the vagina. Lamina propria and sub mucosa made of collagenous dense connective tissue with abundant arterial and venues plexus. Simple tubular glands observed at the base of secondary folds of endocervix and midcervix. The muscularis layer contained of inner circular and outer longitudinal smooth muscles. Serous layer covered the cervix from the outside. Conclusion: Our finding showed that the cervix uteri in Caspian miniature horse, like other horses and ruminants, are a collagenous structure, with tall longitudinal fold throughout the length. Secretion of mucus from the mucosal glands is less obvious than ruminant.
\end{abstract}

Key words: Caspian miniature horse, histology, endocervix, exocervix

\section{INTRODUCTION}

Caspian Miniature horse is an ancient breed of small horses rediscovered on the southern shores of the Caspian Sea in 1960 and small numbers of them exist in a semi-feral state in the rice paddies, cotton fields and forests of the remote Elburz Mountains with governmental protection to prevent extinction. Low rates of reproduction as usually referred to the horses, has been mentioned by Leblanc (2008); Nielsen (2005) and Riddle et al. (2007) is also have been a problem in this species due to many aspects of pathological processes of the genitalia. Pathologists ask to know the normal structure of different parts of reproductive system in this species to define the pathologic cases from the normal ones, especially for those cases of infertility or low fertile ones with no clinical signs. One of these problems has been related to the cervix, the valve to close the uterine lumen from the vagina. Referring to the available literatures, cervix shows remarkable anatomical and histological differences among mammalian species (Banks, 1993; Dellmann and Eurell, 1998; Hafez and Hafez, 2000; Huchzermeyer et al., 2005).

Generally, cervix is constituted of three layers, namely: Endomertrium, myometrium and perimetrium. Since the lamina epithelialis mucosae is lined by glandular simple columnar in the cow and women, is glandless and simple columnar in the horse and glandless stratified squamous in canine. The secretory function of the glands is also varies in different species as well as different periods of estrus cycle. The tunica muscular is in most species are well developed and rich in elastic fibers (Banks, 1993; Dellmann and Eurell, 1998). In The women however, the main bulk of the cervix is composed of tough, collage nous tissue

Corresponding Author: M. Rezaian, Division of Histology, Department of Basic Sciences, Faculty of Veterinary Medicine, University of Tehran, P.O. Box 14155-6453 , Tehran, Iran Tel: +98 2161117117 
containing smooth muscles (Fawcett and Fawcett, 1994; Young and Heath, 2000). Cervical mucosa which is generally characterized by longitudinal primary papilla and secondary and tertiary papillae on the top of them in most species, in small ruminants, however, many shallow, uniform and parallel longitudinal grooves cover the entire surface (Goswami and Wani, 2008). Since no cleared observations have been found in regards with the Caspian miniature horses' cervix, the aim of the present study was to supplement this missing information which could be helpful for providing a stricter basis in detecting reproductive diseases and abnormalities in this valuable species.

\section{MATERIALS AND METHODS}

Cervices of four healthy adult Caspian miniature horses with 3-4 years of ages, had been purchased for a general anatomical research, were used immediately after bleeding from common carotid arteries and fixative were injected through them. To prevent the seasonal variation, all samples were taken in May (beginning of breeding season). Clinical examinations were used before bleeding by rectal examination and checking the whole genitalia, taking bacterial swabs from vaginas, cervices and the uterine bodies and pathological examinations were used after taking out the reproductive systems from the bodies. Rectal examination before and checking the ovaries and observing the follicles after bleeding, revealed that all four animals were in the follicular phase. The whole cervices were then separated from the uterine bodies and vaginas and each were divided into 3 equal parts, from end cervices to exocervices and fixed with $10 \%$ buffered formalin according to Amborgi (1960). Routine histological laboratory methods were used and $6 \mu \mathrm{m}$ paraffin slides were stained with hematoxylineosin for general histological identification, Periodic acid-Schiff for identifying the presence of mucin in the cells, Masson's trichrome for collagen fibers and verhoeff for elastic fibers, all according to Amborgi (1960) and studied under the light microscope. Heights and width of 5 primary fold, secondary fold and tertiary papillae and mucosal glands were measured in 10 slides $(5 \times 10)$ of each samples by a digital photo microscope (UI-2250C; uEye, Germany) connected to a personal computer and image analysis software (Ziess axio vision LE). All measurement's mean values and standard deviations quantified. Data analyzed by a two factor ANOVA test.

\section{RESULTS}

The cervices with the mean length of $4.5 \pm 0.2 \mathrm{~cm}$ and diameter of $2.5 \pm 0.2 \mathrm{~cm}$ were constricted caudal part of the uteri and joined the uterus to the vagina. The endomertrium of cervices were comprised of wide and large longitudinally arranged primary folds with secondary and tertiary folds on them Fig. 1a. Simple columnar epithelium with alternatively arranged ciliated and secretary cells covered the mucosa, had been changed to the non keratinized stratified squamous and a transitional form of stratified squamous with columnar and goblet cells at the top of them at the end of the exocervices, before connecting to the vagina Fig. 2A. PAS staining samples showed low amount of mucin contained into the secretory cells of endocervices, were increased thoroughly toward exocervices. The sub epithelial loose connective tissue contained fibroblasts, fibrocytes, Eosinophil, mast cells, Neutrophil and lymphocytes which were spred especially in the sub epithelia of the endocervices and some of the lymphocytes embedded into the deep recess in the base of the epithelial cells Fig. 2B. The dense connective tissues which filled the sub mucosa and extended to the primary folds were mostly of collagen fibers and few elastic fibers, revealed by Masson's trichrome and verhoeff staining slides. The innermost muscle fibers of the circular muscle layer were continued into the basilar parts of the primary folds.

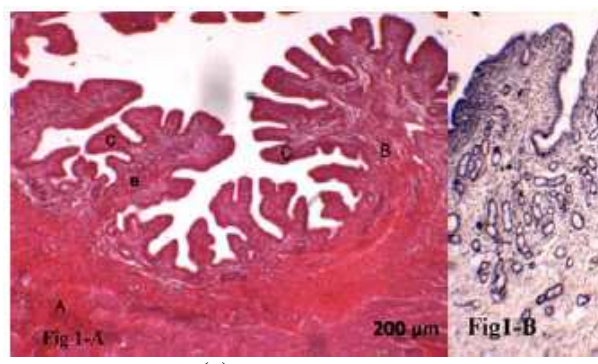

(a)

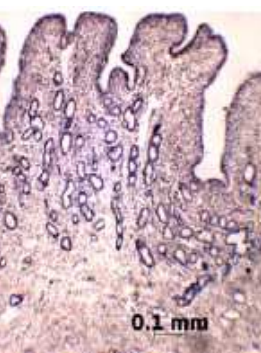

(b)

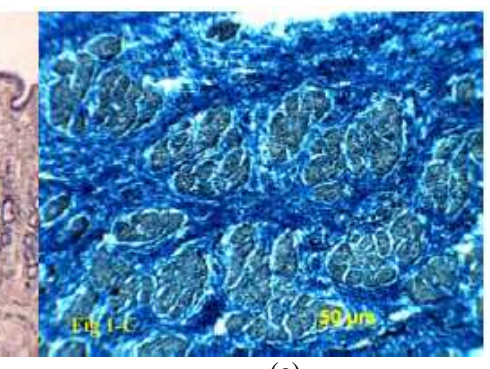

(c)

Fig. 1: Endocervix of Caspian miniature horse. (a): The primary fold (A), Secondary folds (B) and tertiary folds; (C) ( $\mathrm{H}$ and E, $32 \mathrm{x}$ ); (b) Mucosal glands (PAS, 32x); (c) Circular muscle layer criss- crossing with bundles of collagen fibers $\mathrm{c}$ (trichrome mason, 400x) 


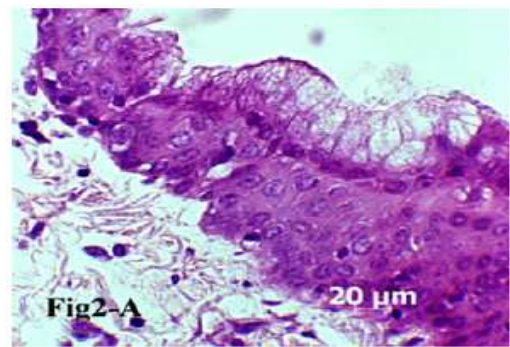

(A)

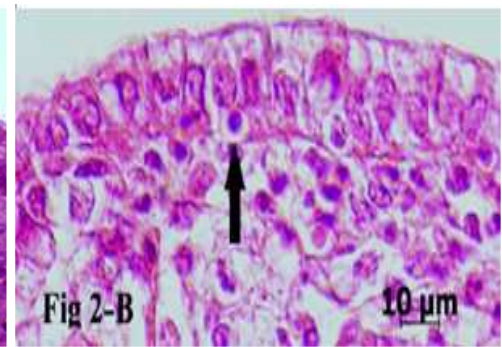

(B)

Fig. 2: Exocervix of Caspian miniature horse; (A) Non keratinized stratified squalors epithelium covered by simple columnar cells at the top, has been observed in the exocervices before connecting to the vagina $(\mathrm{H}$ and $\mathrm{E}, 400$ $\mathrm{x}$ ); (B) simple columnar epithelium covered most parts of the exocervices, lymphocyte in the epithelial cell recess (arrow), (H and E, 1000x)

Table 1: Heights and width of the primary, secondary and tertiary mucosal folds and mucosal glands Morphometrical measurements of the heights and widths of the mucosal folds, mucosal papillae and the mucosal glands

\begin{tabular}{|c|c|c|c|c|c|c|c|c|}
\hline & \multicolumn{2}{|l|}{1 folds } & \multicolumn{2}{|l|}{2 folds } & \multicolumn{2}{|l|}{3 folds } & \multicolumn{2}{|c|}{ Mucosal glands } \\
\hline & $\begin{array}{l}\text { Height } \\
(\mathrm{mm})\end{array}$ & $\begin{array}{l}\text { Width } \\
(\mathrm{mm})\end{array}$ & $\begin{array}{l}\text { Height } \\
(\mathrm{mm})\end{array}$ & $\begin{array}{l}\text { Width } \\
(\mathrm{mm})\end{array}$ & $\begin{array}{l}\text { Height } \\
(\mathrm{mm})\end{array}$ & $\begin{array}{l}\text { Width } \\
(\mathrm{mm})\end{array}$ & $\begin{array}{l}\text { Height } \\
(\mathrm{mm})\end{array}$ & $\begin{array}{l}\text { Width } \\
\text { (mm) }\end{array}$ \\
\hline Region 1 & $7.25 \pm 0.51$ & $0.41 \pm 0.06$ & $0.72 \pm 0.12$ & $0.25 \pm 0.01$ & $0.14 \pm 0.03$ & $0.08 \pm 0.01$ & $0.45^{\mathrm{a}} \pm 0.06$ & $0.04 \pm 0.01$ \\
\hline Region 2 & $7.19 \pm 0.31$ & $0.43 \pm 0.08$ & $0.72 \pm 0.10$ & $0.23 \pm 0.02$ & $0.14 \pm 0.02$ & $0.07 \pm 0.03$ & $021^{\mathrm{b}} \pm 0.03$ & $0.03 \pm 0.01$ \\
\hline Region 3 & $7.18 \pm 0.53$ & $0.40 \pm 0.04$ & $0.73 \pm 0.14$ & $0.23 \pm 0.06$ & $0.12 \pm 0.04$ & $0.08 \pm 0.03$ & $0^{\mathrm{c}}$ & 0 \\
\hline
\end{tabular}

Values given are mean \pm SD; Superscript letters ${ }^{\mathrm{b}, \mathrm{c}}: \mathrm{p}<0.05,{ }^{\mathrm{a}, \mathrm{c}}: \mathrm{p}<0.05,{ }^{\mathrm{a}, \mathrm{b}}: \mathrm{p}<0.05$

Simple tubular glands with columnar epithelium were observed at the base of the secondary folds and loosely packed into the lamina propria in Regions 1 and 2 (endocervices and midcervices) and were absent in the exocervices Fig. 1b. The epithelial cells of the glands were similar to the mucosal epithelia with lesser amounts of ciliated cells and higher secretory columnar cells. Blood vessels were present at the deep of the lamina propria in the form of arterioles and venules, ascending towards the surface epithelia with smaller branches and capillaries, were more obvious in the exocervices. The tunica muscularis were in two layers of inner thick circular and outer longitudinal smooth muscle cells, both crises-crossing with the thick bundles of collagen fibers Fig. 1c. A small vascular layer observed between the two muscle layers. Tunica serosa covered the cervix from the outside.

Measurement of the heights and widths of the primary, secondary and tertiary folds showed that there were no significant differences between these sizes in three regions of cervices. Table 1 displays the heights and widths of the mucosal folds and mucosal glands.

\section{DISCUSSION}

Microscopic structure of the cervices in different animal's as well as human have been mentioned by
Dellmann and Eurell (1998); Banks (1993); Fawcett and Fawcett (1994) and Hafez and Jaszczak (1972). The recent study characterized the Caspian miniature horse cervix more precisely and declares the similarities/differences between Caspian horses and other animals.

Goswami and Wani (2008) suggested that the cervical mucosa in small ruminants is generally characterized by longitudinal primary fold most of which maintained continuity throughout the cervix. Hafez and Jaszczak (1972) showed that the cervical mucosa in baboon, marmoset and patas monkeys contained a large amount of clefts and tubular tunnels of variable structure, length, width, direction and degree of branching. They also found that the mucosa in macaques contained a large number of crypts with complex structure, length, width, direction and degree of branching, which were longer in exocervix, whereas, small crypts, clefts and long tunnels existed in the midcervix. While as our findings, the cervical mucosa lined by a single layer of tall columnar cells in human, primates, ruminants and horse, is vaginal type of mucosa with stratified squamous epithelium that undergoes cyclic alteration as in the vagina in pig and dog (Dellmann and Eurell, 1998). The structure of the mucosal folds in our finding was similar to the ruminants and horse and was differ from the primates 
and human as they have different crypts and clefts and tunnels instead of longitudinal folds. Presence and structure of the mucosal gland is also varied in different animals, since no gland is observed in swine and dog (Dellmann and Eurell, 1998; Banks, 1993), ruminants have simple tubular glands with mucin secretion (Dellmann and Eurell, 1998). Our finding about the mucosal glands was similar to the ruminants in somehow such as its structure, but differ, as its secretion with low amount of mucin and existing only in endocervices and mid cervices and absence in exocervices.

Venus plexus that have been mentioned by Dellmann and Eurell (1998) in the deep part of the lamina propria-submucosa of the cervices of mares and bitches, was also exist in our samples, but they were more abundant in exocervices, where the glands was absent.

Like our findings, Goswami and Wani (2008) showed that the greater proportion of cervical wall in small ruminants was composed up of dense fibrous connective tissue consisting of collagen fibers. Also referring to the Junqueira et al. (1995), the collagen fiber in the women made the solidity of cervical canal. Whereas Shahrooz et al. (2009) declared that elastic fibers be plentiful in mucosa and sub mucosa and muscular layer of the cervices in all animals.

\section{CONCLUSION}

The cervix uteri is a collagenous structure in Caspian Miniature Horses with a single layer of tall columnar epithelium lining the mucosa in the most parts of its length and change to the nonkeratinized squamous epithelium near the vagina. Mucosal gland exists only in endocervices and midcervices. Submucosa filled with thick bundles of collagen fibers and muscularis layers crises-crossed with the same bundles of collagen fibers as well.

\section{REFERENCES}

Amborgi, L., 1960. Manual of Histologic and Special Staining Techniques. McGraw-Hill Book Company, New York, pp: 207.

Banks, W.J., 1993. Female reproductive system. Applied Veterinary Histology. 3rd Edn., MosbyYear Book, Inc., St Louis, ISBN: 10: 0801666104, pp: 527.
Dellmann, H.D. and J. Eurell, 1998. Textbook of Veterinary Histology. 5th Edn., Lippicott Williams and Wilkins, Philadelphia, ISBN: 10: 0683301683, pp: 380 .

Fawcett, D.W. and D. Fawcett, 1994. A Textbook of Histology. 12th Edn., A Hodder Arnold Publication, ISBN: 0412981912, pp: 988.

Goswami, P. and G.M. Wani, 2008. Cervical alterations during pregnancy in small ruminants. ArticlesBase. http://www.articlesbase.com/sciencearticles/cervical-alterations-duringpregnancy-insmall-ruminants-442936.html

Hafez, E.S.E. and B. Hafez, 2000. Reproduction in Farm Animals. 7th Edn., Wiley-Blackwell, Philadelphia, ISBN: 13: 978-0683305777, pp: 509.

Hafez, E.S.E. and S. Jaszczak, 1972. Comparative anatomy and histology of the cervix uteri in nonhuman primates. Primates, 13: 297-314. http://www.springerlink.com/content/u625m827hn $141148 /$

Huchzermeyer, S., A. Wehrend and H. Bostedt, 2005. Histomorphology of the equine cervix. Anat. Histol. Embryol., 34: 38-41. PMID: 15649225

Junqueira, L.C., J. Carneiro and R.O. Kelly, 1995. Basic Histology. 1st Edn., McGraw-Hill/Appleton and Lange, California, ISBN: 10: 0838505872, pp: 456.

Leblanc, M.M., 2008. When to refer an infertile mare to a theriogenoloist. Theriogenology, 70: 421-429. PMID: 18514809

Nielsen, J.M., 2005. Endometritis in the mare, a diagnostic study comparing cultures from swab and biopsy. Theriogenology, 64: 510-518. DOI: 10.1016/J.Theriogenology.2005.05.034

Riddle, W.T., M.M. Leblanc and A.J. Stromberg, 2007. Relationships between uterine culture, cytology and pregnancy rates in a thoroughbred practice. Theriogenology, $\quad 68:$ 395-402. http://www.theriojournal.com/article/S0093691X(07)00279-8/abstract

Shahrooz, R., E. Ayan and B. Rustami, 2009. Histological study of cervix in adult Azarbayejanii buffalo in estrus cycle. J. Vet. Res., 64: 121-125.

Young, B. and J.W. Heath, 2000. Wheater's Functional Histology: A Text and Color Atlas. 4th Edn., Churchill Living Stone, Edinburgh, ISBN: 0-44305618-8, pp: 413. 